\title{
PONTO
}

DE VISTA

\section{Algumas Verdades sobre a Clínica Fisiátrica do Ombro Doloroso}

\author{
R.E. de Araujo Leitão* \\ Valéria de Araujo Leitão**
}

Em caso de ombro doloroso determinado por bursite aguda, não aplique nenhuma forma de calor. Tal procedimento irá certamente aumentar o sofrimento do paciente. Aplique gelo e mantenha o ombro em repouso. Prescreva uma tipóia.

Nas bursites agudas do ombro ou de qualquer outra região do corpo, aplique gelo durante dez a quinze minutos, de duas em duas horas. Alivia a dor e reduz o processo inflamatório.

No ombro doloroso provocado por tendinite calcificada ou por artropatia não inflamatória, use calor sob a forma de infravermelho, diatermia ou ultra-som, duas vezes ao dia, durante quinze minutos. Alivia a dor e não tem contra-indicações.

Dor no ombro esquerdo, de causa ainda não esclarecida, não faça tração, julgando tratar-se de patologia da coluna cervical. Pode ser infarto do miocárdio.

Lembre-se que $85 \%$ das causas de ombro doloroso estão nas lesões músculo-esqueléticas da articulação, portanto, localizamse na bainha rotatória e na longa porção do bíceps, ou seja, as lesões são predominantemente tendo capsulares.

\section{Segundo as estatísticas:}

$75 \%$ dos casos de ombro doloroso são de patologia tendocapsular;

$20 \%$ são de patologia articular; nal).

$05 \%$ têm origem em dor referida (cervical, torácica ou abdomi-

Lembre-se que, o sucesso terapêutico na síndrome ombromão está na precocidade do atendimento. E valem todos os recursos admissíveis pela medicina.

Anote bem: o chamado ombro bloqueado, capsulite retrátil, ombro gelado etc. é uma algo-neurodistrofia e tem uma evolução demorada e resistente ao tratamento. Não desanime. Dê todo o apoio ao paciente e use os meios terapêuticos necessários que

* Médico da Academia Nacional de Medicina e da Academia de Medicina de Reabilitação.

** Médica do Serviço de Fisiatria do Instituto de Neurologia Deolindo Couto - UFRJ 
puder dispor. Na pior hipótese, a afecção desaparece após um ou dois anos.

Atenção para o ombro esquerdo doloroso, causado por afecção à distância (dores referidas). Esteja alerta sobretudo para o ombro doloroso de sintomatologia vaga, não definida, acompanhada ou não de cervicalgia. Pode tratar-se de infarto de miocárdio.

Em pessoas idosas, não se preocupe demasiadamente com a laceração ou a ruptura do tendão do bíceps. A incapacidade física é pequena, o sofrimento é discreto e a cirurgia só deve ser indicada em casos muito especiais.

Lembre-se que, existem neuropatias de compressão e outras patologias neurológicas que podem ser responsáveis pela dor no ombro. Exemplos: compressão do n. supra-escapular, do n. escapular dorsal, do plexo braquial, de raizes cervicais, da medula espinhal.

Violenta dor no ombro,de súbito aparecimento, com irradiação para o pescoço e para o braço nem sempre é bursite aguda. Pode representar o início da síndrome de Parsonage-Tuner, afecção neurológica provavelmente de causa viral. A dor desaparece quando surge a paralisia.
Atente para o seguinte: o ombro doloroso agudo de causa músculo-esquelética requer seguramente como tratamento inicial: repouso da articulação analgésicos e anti-inflamatórios. E aplicações de gelo várias vezes ao dia.

A melhor terapêutica preventiva das complicações do ombro doloroso é a cinesiterapia ativa através dos exercícios de Codman e de alongamento da musculatura comprometida.

A fim de evitar o edema da mão e dos dedos na síndrome ombro-mão é indispensável a realização de exercícios do ombro, do cotovelo e de preensão, que funcionam como bombeamento.

\section{Referências Bibliográficas}

1. CAILLIET, RENÉ. Sindromes dolorosos - OMBRO, Editora Manole, 1976.

2. RODELLE, BERNARD. Reumatologia para o clínico geral, Organização Andrei Editora Ltda., 1983.

3. SEDA, HILTON. Reumatologia, vol. Il, Editora Cultura Médica, $2^{\circ}$ edição, 1982 (Gonçalves, Geraldo Wilson. Ombro doloroso)

4. TUREK, SAMUEL L., Ortopedia, Princípios y Aplicaciones, Salvat Editores S.A., Tomo II, 1982.

5. LEMOS, MIRIAM MAIA. LIMONGE, ZOROASTRO FONSECA, CARNEIRO, ARMANDO PEREIRA. Síndrome compreessiva do nervo supra-escapular. Resumos de casos e revisão da literatura. Medicina de Reabilitação, $n^{\circ} 37$ e 38, 1994. 